\title{
Who cares for the nine million displaced people of Syria?
}

The civil war that started in 2011 has forced millions of Syrians to flee their homes, many of them children. Richard Hurley spoke to three volunteers for the charity Doctors of the World, which brings essential medical care to the world's most vulnerable people. We've chosen the charity for the BMJ's Christmas appeal this year. Please give generously

\section{Richard Hurley deputy magazine editor}

$B M J$, London, UK

\begin{abstract}
"Zaatari camp is considered the fourth biggest city in Jordan," a volunteer medical coordinator who had recently been working there told me last week. She was speaking from the Paris headquarters of Doctors of the World. The charity asked us to keep its volunteers' identities confidential as healthcare professionals and facilities have been targets for violence. Just inside the border, the Zaatari refugee camp began only a year and a half ago but has exploded to a population of well over 100000 Syrian men, women, and children. The charity Doctors of the World manages and staffs two medical centres in the camp and one in a nearby town.

"This situation is new for Jordan and overwhelming," according to a volunteer pharmacist. Each centre has two general practitioners, four nurses, one psychologist, and a pharmacist and provides free primary care and drugs. Doctors of the World is also helping the Jordanian Ministry of Health train staff to respond to outbreaks of infectious disease.
\end{abstract}

"In the summer the biggest fear was cholera as there were cases of bloody diarrhoea. It's particularly dangerous in a closed community because it's so contagious," she said. But no outbreak came. "The fear now is polio, which Jordan has not seen for many years, with 10 confirmed cases." Vaccination campaigns are taking place, she confirmed.

She also said that refugees' pre-existing illnesses are being neglected: "Diseases like diabetes and hypertension are quite a challenge. In an emergency context nobody thinks about non-communicable disease. No one thought the crisis would last this long.

"We have to move from thinking about health emergencies to think about post-war, the long term, and not just about outbreaks and communicable disease but about people who already have health problems," she added.
Zaatari's residents are also experiencing mental health problems: "Post-traumatic stress disorder and depression are quite common in the camp, especially for children, who often suffer from enuresis because they don't always know how to express themselves.

"Some people don't want to be thought of as refugees," she continued. If refugees do not register as such they are often denied care through Jordan's secondary care system. "When we want to refer patients, if they are registered it's simple: they can see any specialist. Unregistered refugees are treated as foreign, though, and have to pay, but many don't have the money. There are no barriers to registration, but the problem is stigma.

"Secondary and tertiary care are the responsibility of the Jordanian Ministry of Health and a big burden so maybe NGOs [non-governmental organisations] should think about this and not just support primary care."

\section{Difficult conditions}

A doctor volunteer who'd been working with displaced people around the city of Aleppo, close to Syria's border with Turkey, for the past 10 months, told me that humanitarian organisations are struggling to keep up as people keep moving and the camps swell in population. "The biggest problem is the cold-they need blankets and more tents. There is also a shortage of food," he said. "And much more needs to be done about sanitation."

As well as the refugee camps, "every village in northern Syria also has internally displaced people," he said.

His pharmacist colleague mentioned other dangers: "People have a lot of stress and they feel angry. So it's easy for them to use their guns. Sometimes we have dead people, but it's not the regime or rebels; they are simple fights but people have guns." 
"We are afraid of polio," she continued. "We've never seen a patient with polio in our camps, but we know in other parts of our country there are more than 25 children who have it."

Seven doctors hold 8000 medical consultations a month in one of the centres coordinated by Doctors of the World that serves refugees in the Aleppo area, providing primary care, including vaccinations, help with family planning, and obstetric and gynaecological care.

About half of all consultations are for respiratory tract infections, and diarrhoea and skin diseases such as scabies and eczema are also major problems among displaced people, the pharmacist said. Leishmaniasis is also prevalent.

In terms of non-communicable disease, she said, "We assess children with epilepsy and take drugs to them, and we have a doctor to assess chronic disease, particularly diabetes and hypertension.

"Insulin supplies are not sufficient, and in diseases like multiple sclerosis, liver cirrhosis, or malignancy we can't provide drugs, and we try to send patients to Turkish hospitals," she said. "We have a lot of psychiatric problems inside our camps, and we are hoping to get a doctor specialising in psychiatry."

When I asked why she had volunteered for Doctors of the World, she explained, "I'm also a refugee in Turkey. When we left Syria I left my job. This is my opportunity to help my people." The doctor spoke again: "70\% of people in Syria cannot get help from state facilities because of political and security issues. A lot of hospitals have been targeted, and 160 doctors have been killed.
"After the crisis we will have a lot of disabled people. Humanitarian aid will be needed for decades. My concern is that NGOs and donors will gradually lose interest. I hope that NGOs like Doctors of the World continue with the same motivation," he said.

Made up of 14 independent national organisations, the charity currently has 3000 volunteer doctors, surgeons, nurses, managers, and health workers working in more than 300 programmes in 70 countries, many of which are long term.

Recent figures from the United Nations suggest some nine million people are in need as a result of the fighting in Syria, including two million who have fled the country, half of whom are children. Some 100000 adults and children have died so far. Without help from organisations such as Doctors of the World the number would be likely to be far higher.

See Jane Feinmann's first feature on Doctors of the World, which focused on the charity's work bringing medical care to survivors of typhoon Haiyan in the Philippines (doi:10.1136/bmj.f7193).

\section{Cite this as: BMJ 2013;347:f7374}

\section{Related links}

\section{bmj.com}

- Feature: After the typhoon: how volunteer doctors are bringing medical care to those most in need (BMJ 2013; 347:f7193)

C BMJ Publishing Group Ltd 2013 


\section{Please give generously to Doctors of the World}

A donation of $£ 50$ could help provide 10 families with hygiene kits or blankets; $£ 100$ could provide psychological consultations for 20 Syrian refugees. To donate go to www. doctorsoftheworld.org.uk/BMJ or phone +44 (0)20 35357955 . To donate $£ 10$ by text message text DOCTOR to 70030 (UK mobiles only).

\section{Figure}

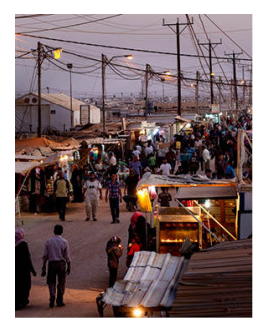

